\title{
Yield and Quality of Spinach Cultivars for Spring Production in Oklahoma
}

\author{
Lynn Brandenberger ${ }^{1}$, \\ Lynda K. Wells ${ }^{2}$, and \\ Michel M. Haigh ${ }^{3}$
}

AdDitional InDEX wORDs. Spinacia olevacea, bolting, long standing, hybrid, open pollinated

Summary. Nine (2001) and eight (2002) spinach (Spinacia oleracea) cultivars, including hybrid and open pollinated types, were tested for yield and quality characteristics during two spring production seasons in Oklahoma. Cultivars were evaluated for emergence, vigor, color, bolting resistance, and yield. Cultivars did not vary significantly for yield, which ranged from 11.9 to 14.9 tons/acre. 'Baker', 'Bolero', 'Catalina', 'Olympia', and 'Padre' had significantly higher levels of bolting resistance than other cultivars in the trials. 'Catalina', 'Olympia', and 'Padre' also exhibited the darkest green color of those cultivars with bolting resistance. Based upon bolting resistance, 'Catalina', 'Olympia', 'Padre', 'Baker', and 'Bolero' are five cultivars that can be recommended for use in spring planted spinach in Oklahoma and the southern plains.

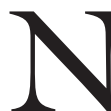

ationwide, there were 45,120 acres (18,260 ha) of spinach in 2002 [U.S. Department of Agriculture (USDA), 2003], of

Acknowledgements. The authors appreciate the support and efforts of Merlin Schantz, Dean Smith, T.E. Morelock, William Russell, Bill Gebhardt, and Bruce Bostian in completing this work.

This research has been supported in part by the Oklahoma Agricultural Experiment Station.

${ }^{1}$ Oklahoma State University, Department of Horticulture and Landscape Architecture, 360 Agriculture Hall, Stillwater, OK 74078-6027; e-mail: lpb@okstate.edu

${ }^{2}$ Oklahoma State University, Department of Horticulture and Landscape Architecture, 360 Agriculture Hall, Stillwater, OK 74078-6027; e-mail: wlynda@okstate. edu.

${ }^{3}$ Oklahoma State University, Department of Agriculture Communication Services, 117 PIO Bldg., Stillwater, OK 74078-6041. 
which 31,600 (12,789 ha) were fresh market, and 13,520 (5,472 ha) were for processing (USDA, 2003). During the past 10 years, acreage of fresh spinach increased approximately 1.5 times while that of processing spinach has remained steady (USDA, 1995, 2003). California produced the majority of the fresh market spinach (USDA, $1995,2003)$. Other states, including Oklahoma, are examining potential new markets for spinach. The majority of spinach in Oklahoma has been for fall and over-winter production in the canning and freezing industry, with a smaller amount committed to fresh market. Currently, spinach acreage in Oklahoma is approximately 3000 acres (1214 ha).

Increased spinach production and consumption during the past decade can be attributed to spinach salad products and growing public awareness of the health benefits of spinach (Silva, 2002). Spinach provides dietary fiber and supplies high levels of both vitamins and minerals (Leskovar et al., 2000). Goldman (2003) described foods as "functional" when they have health benefits in addition to fulfilling the nutritional requirements of humans. One health benefit of several vegetables, including spinach, is increased antioxidant intake in diets (McCord and McVeigh, 2000).

Numerous aspects of spinach production have been evaluated in cultivar trials, including emergence, yield, growth habit, color intensity, bolting, and pest resistance (Dainello, 1989; Dainello et al., 1987; De Rooster and Spiessens, 1998; Djurovka et al., 1988; Gorini and Testoni, 1990; Sneep, 1982). Crop emergence is an important aspect of production. Dainello (1989) noted that several field conditions can influence the emergence of vegetable crops. Poor emergence can increase the time from planting to harvest and reduce yield. Yield has been included in a majority of studies and is considered to be a key component of cultivar selection (Dainello et al., 1984, 1987; Djurovka et al., 1988). Williams and Roberts (2002) reported that "marketable yield" was the most important factor to producers surveyed to determine the importance of 13 different factors in watermelon (Citrulluslanatus) cultivar evaluations. High yield potential of a spinach cultivar is a requirement for crop profitability.

Spinach color intensity has been an important aspect of testing for several investigators (Dainello et al., 1984; Gorini and Testoni, 1990; Tonini et al., 1987). Dark green color is considered an important attribute that consumers utilize when selecting either fresh or frozen spinach (Gorini and Testoni, 1990). Murphy and Morelock (1999) noted that dark green vegetables have high levels of carotenoids. They also reported a strong correlation between the concentration of lutein and chlorophyll-a (Murphy and Morelock, 2000), which indicates the potential for visually selecting higher levels of lutein.

Flowering and seed stalk formation (bolting) in spinach renders the crop unmarketable (Knott, 1939). Spinach breeders have been selecting for bolting resistance (longstanding) since the 19th century, and this continues today (Sneep, 1982). Day length controls flowering and subsequent seed stalk formation (Chun et al., 2001). Chun et al. (2001) found that the percentage of flowering spinach plants increased from $0 \%$ at 10 -h day lengths to $85 \%$ and higher when plants received 16-h day lengths.

The objective of this 2-year study was to determine the suitability of spinach cultivars for spring production in Oklahoma. Production attributes included in the studies were leaf yield, seedling emergence and vigor, leaf color intensity, and bolting resistance. Cultivar responses to environmental conditions, particularly the increasing day lengths of spring, were an important aspect of the study.

\section{Materials and methods}

Spinach cultivars were evaluated during the spring production seasons of 2001 and 2002 at the Vegetable Research Station in Bixby, Okla., and in producers' fields in Caddo and Custer counties in west-central Oklahoma during 2001. Test sites were selected on the basis of representing the two major spinach production areas within the state. Nine spinach cultivars from three seed companies were included in the tests at each site in 2001, and all except 'F-380' were included in the 2002 test. Leaf types of the different cultivars ranged from smooth to savoy (crinkled), representing the major types of spinach produced in the region.

SOILS AND CROP CULTURAL PRACTICES. Soils and crop cultural practices were similar at each site (Table 1 ).
Soils ranged from coarse to fine silts. Fertility was managed at each site based on Oklahoma Cooperative Extension recommendations and soil test results. Fertilizer applied included 80 to 120 $\mathrm{lb} /$ acre $\mathrm{N}\left(89.7\right.$ to $\left.134.5 \mathrm{~kg} \cdot \mathrm{ha}^{-1}\right)$ in two applications (preplant and sidedress 14 to $21 \mathrm{~d}$ after emergence), and preplant applications of $\mathrm{P}$ at 0 to 60 $\mathrm{lb} /$ acre $\left(67.2 \mathrm{~kg} \cdot \mathrm{ha}^{-1}\right)$ and $\mathrm{K}$ at 0 to $30 \mathrm{lb} /$ acre $\left(33.6 \mathrm{~kg} \cdot \mathrm{ha}^{-1}\right)$. Weed control at all sites was with $0.64 \mathrm{lb} /$ acre $\left(0.717 \mathrm{~kg} \cdot \mathrm{ha}^{-1}\right)$ a.i. of S-metolachlor (Syngenta, Greensboro, N.C.) as a preemergence application following planting. No other pest control measures were utilized at the test sites. Spinach at all sites received supplemental water as needed through overhead irrigation, with each site receiving 1 to 2 inches (25.4 to $50.8 \mathrm{~mm}$ ) from rainfall or irrigation per week.

STATISTICAL DESIGN AND ANALYSIS. All tests were arranged in a randomized complete-block design with four replications. Data sets from each of the four tests were combined and analyzed using analysis of variance (PROC GLM), and means were separated using Duncan's multiple range test where $P=0.05$ with SAS version 8.2 (SAS Institute, Cary, N.C.). Percent emergence data were arcsin transformed and analyzed, but are reported as percent emergence.

Study establishment. Spinach was direct seeded in early March in 2001 and 2002 (approximately 11.5 -h day length). Test sites in Caddo and Custer counties were direct seeded using a Powell Cole, Planet Jr. hand-push seeder (Powell Manufacturing Co., Bennettsville, S.C.). A cone planter (Kincaid Manufacturing, Haven, Kans.) with a double disk opener was used both years at Bixby. Seeding rates for the four tests averaged 566,500 seeds/acre $(1,399,802$ seeds/ha). Plots included two rows of spinach with either 10,12 , or 15 inches between rows $(25.4,30.5$, or $38.1 \mathrm{~cm})$ and were 20 or $30 \mathrm{ft}$ long $(6.1$ or $9.1 \mathrm{~m})$

EMERGENCE. Ratings for percentage of emerged plants were taken 20 $34 \mathrm{~d}$ after seeding (DAS). Plots were rated visually for the percentage of emerged plants.

VIGOR. Seedling vigor ratings based upon rate of growth were taken between 34-43 DAS. Plants in each plot were rated on a 1 (low level of vigor) to 5 (high level of vigor) rating scale with 1.5 considered to be the minimum acceptable level of vigor. 
Table 1. Yield and quality of spinach cultivars for spring production in Oklahoma: site location, planting date, between row spacing, seeding rate, soil classification, fertilizer applied, and irrigation methods.

\begin{tabular}{|c|c|c|c|c|c|c|}
\hline $\begin{array}{l}\text { Site, } \\
\text { year, and } \\
\text { planting date }\end{array}$ & $\begin{array}{c}\text { Between } \\
\text { row } \\
\text { spacing } \\
\text { (inches) }^{z}\end{array}$ & $\begin{array}{c}\text { Seeding } \\
\text { rate } \\
\text { (seed/acre) }^{u}\end{array}$ & $\begin{array}{c}\text { Soil } \\
\text { classification }\end{array}$ & $\begin{array}{c}\text { Fertilizer } \\
\text { applied }\end{array}$ & $\begin{array}{c}\mathrm{N}-\mathrm{P}-\mathrm{K} \\
\text { applied } \\
(\mathrm{lb} / \text { acre })^{\mathrm{t}}\end{array}$ & $\begin{array}{c}\text { Actual } \\
\text { Irrigation }\end{array}$ \\
\hline $\begin{array}{l}\text { Bixby } 2001 \\
14 \text { Mar. } 2001\end{array}$ & 15 & 558,000 & $\begin{array}{l}\text { Coarse-silty, mixed, calcareous, } \\
\text { thermic Typic Udifluvents }\end{array}$ & $\begin{array}{l}\mathrm{N} \\
\mathrm{P} \\
\mathrm{K}\end{array}$ & $\begin{array}{r}80 \\
0 \\
0\end{array}$ & $\begin{array}{l}\text { Overhead from } \\
\text { pipe and risers }\end{array}$ \\
\hline $\begin{array}{l}\text { Bixby } 2002 \\
14 \text { Mar. } 2002\end{array}$ & 15 & 558,000 & $\begin{array}{l}\text { Coarse-silty, mixed, calcareous, } \\
\text { thermic Typic Udifluvents }\end{array}$ & $\begin{array}{l}\mathrm{N} \\
\mathrm{P} \\
\mathrm{K}\end{array}$ & $\begin{array}{r}80 \\
0 \\
0\end{array}$ & $\begin{array}{l}\text { Overhead from } \\
\text { linear system }\end{array}$ \\
\hline $\begin{array}{l}\text { Caddo } 2001 \\
6 \text { Mar. } 2001\end{array}$ & 10 & 627,264 & $\begin{array}{l}\text { Coarse-silty, mixed, thermic } \\
\text { Udic Haplustolls }\end{array}$ & $\begin{array}{l}\mathrm{N} \\
\mathrm{P} \\
\mathrm{K}\end{array}$ & $\begin{array}{r}120 \\
60 \\
30\end{array}$ & $\begin{array}{l}\text { Overhead from } \\
\text { piot system }\end{array}$ \\
\hline $\begin{array}{l}\text { Custer } 2001 \\
5 \text { Mar. } 2001\end{array}$ & 12 & 522,720 & $\begin{array}{l}\text { Fine-silty, mixed, thermic, } \\
\text { Pachic Argiustolls }\end{array}$ & $\begin{array}{l}\mathrm{N} \\
\mathrm{P} \\
\mathrm{K}\end{array}$ & $\begin{array}{c}96.5 \\
0 \\
0\end{array}$ & $\begin{array}{l}\text { Overhead from } \\
\text { pivot system }\end{array}$ \\
\hline
\end{tabular}

${ }^{\mathrm{z}} 1.0$ inch $=2.54 \mathrm{~cm}$.

"l.0 seed $/$ acre $=2.47$ seeds $/$ ha.

${ }^{\mathrm{t}} 1.0 \mathrm{lb} / \mathrm{acre}=1.12 \mathrm{~kg} \cdot \mathrm{ha}^{-1}$.

Color. Color ratings were recorded twice for each test. The first ratings were made between $42-60$ DAS and the second ratings 62-69 DAS. Plants were rated on a 1 (lowest level of green color intensity) to 5 (highest level of green color intensity) scale (Dainello et al., 1984).

Bolting. Plants were rated visually for the percentage of bolting just prior to harvest. This was accomplished between 62-69 DAS.

YIELD. Plots were harvested between May 11 and 22 (14 to 14.25-h day lengths) during the 2-year study through the use of manual hedge shears with 9-inch $(22.9 \mathrm{~cm})$ scissortype blades. Spinach was cut about 1.5 inches $(3.81 \mathrm{~cm})$ above the soil surface for a total length of $4 \mathrm{ft}(1.2 \mathrm{~m})$ from the middle of each plot. Harvested spinach was weighed in the field immediately after cutting using an electronic balance (Model DT 60J $100 \mathrm{lb}$; Mettler Toledo, Worthington, Ohio). Yields were calculated and reported in tons per acre based upon plot yields.

\section{Results and discussion}

Stand establishment is essential in the successful production of a crop. 'Bolero' and 'Samish' had significantly more plants emerge than five of the other cultivars tested, but did not differ in emergence compared to 'Padre' and 'F-91-415', (Table 2). Percent emergence was 76 and $75 \%$, for 'Bolero' and 'Samish' and 68 and $65 \%$ for 'Padre' and F-91-415', respectively. Differences in percent emergence did not

Table 2. Yield and quality of spinach cultivars for spring production in Oklahoma: spinach seed source, leaf type, percent emergence, vigor, color, percent bolting, and yield.

\begin{tabular}{lclccccc}
\hline Cultivar & Source $^{\mathrm{z}}$ & $\begin{array}{c}\text { Leaf } \\
\text { type }\end{array}$ & $\begin{array}{c}\text { Emergence } \\
(\%)\end{array}$ & Vigor $^{\mathrm{y}}$ & Color $^{\mathrm{x}}$ & $\begin{array}{c}\text { Bolting } \\
(\%)\end{array}$ & $\begin{array}{c}\text { Yield } \\
{\text { (tons } / \text { acre })^{\mathrm{w}}}\end{array}$ \\
\hline Baker & AC & Smooth & $57 \mathrm{bc}^{\mathrm{v}}$ & $2.6 \mathrm{c}$ & $2.9 \mathrm{e}$ & $1 \mathrm{e}$ & $14.1 \mathrm{a}$ \\
Bolero & RS & Smooth & $76 \mathrm{a}$ & $3.8 \mathrm{a}$ & $2.4 \mathrm{f}$ & $1 \mathrm{e}$ & $14.5 \mathrm{a}$ \\
Catalina & AS & Smooth & $57 \mathrm{bc}$ & $1.8 \mathrm{~d}$ & $4.0 \mathrm{a}$ & $1 \mathrm{e}$ & $12.1 \mathrm{a}$ \\
Cypress & AS & Semi savoy & $54 \mathrm{c}$ & $2.5 \mathrm{c}$ & $3.4 \mathrm{bc}$ & $26 \mathrm{~d}$ & $11.9 \mathrm{a}$ \\
F-380 & AC & Flat & $60 \mathrm{bc}$ & $3.3 \mathrm{~b}$ & $3.1 \mathrm{de}$ & $76 \mathrm{~b}$ & $14.9 \mathrm{a}$ \\
F-91-415 & AC & Semi smooth & $65 \mathrm{abc}$ & $3.2 \mathrm{~b}$ & $3.2 \mathrm{~cd}$ & $53 \mathrm{c}$ & $14.6 \mathrm{a}$ \\
Olympia & AC & Smooth & $58 \mathrm{bc}$ & $2.5 \mathrm{c}$ & $3.6 \mathrm{~b}$ & $0 \mathrm{e}$ & $12.1 \mathrm{a}$ \\
Samish & AC & Savoy & $75 \mathrm{a}$ & $3.4 \mathrm{~b}$ & $3.3 \mathrm{c}$ & $91 \mathrm{a}$ & $14.7 \mathrm{a}$ \\
Padre & AS & Semi savoy & $68 \mathrm{ab}$ & $3.1 \mathrm{~b}$ & $3.5 \mathrm{~b}$ & $0 \mathrm{e}$ & $13.5 \mathrm{a}$
\end{tabular}

${ }^{\mathrm{z}} \mathrm{AC}=$ Alf Christianson Co., Mt. Vernon, Wash.; AS and RS = Asgrow and Royal Sluis, respectively; both are subsidiaries of Seminis Vegetable Seeds, Oxnard, Calif.

yigor rated on a 1 (low amount of vigor) to 5 (high amount of vigor) rating scale.

${ }^{\mathrm{x}}$ Color rated on a 1 (lowest level of green color intensity) to 5 (highest level of green color intensity) scale.

"1.0 ton/acre $=2.24 \mathrm{t} \cdot \mathrm{ha}^{-1}$.

"Numbers in a column followed by the same letter exhibited no significant differences based on Duncan's multiple range test where $P=0.05$.

appear to affect yield at harvest and this agrees with Dainello's (1984) observations that spinach can compensate for differences in plant populations under rapid growth conditions. Therefore, it appears in these trials that all cultivars had acceptable plant populations.

Vigor ratings ranged from 1.8 for 'Catalina' to 3.8 for 'Bolero' (Table $2)$. 'Bolero' was significantly more vigorous than all other cultivars tested. Three cultivars including 'Samish,' 'F-380', and 'F-91-415' had the next highest vigor ratings. Vigor in these trials appeared to be an early indication of yield potential. The four highest yielding cultivars included the four cultivars with the highest vigor rat- ings. Although leaf yields did not vary significantly among entries they ranged from 14.9 tons/acre $\left(33.40 \mathrm{t} \cdot \mathrm{ha}^{-1}\right)$ to 11.9 tons/acre $\left(26.68 \mathrm{t} \cdot \mathrm{ha}^{-1}\right)$ (Table 2). 'F-380,' 'Samish,' 'F9l-415,' and 'Bolero' had the four highest yields which were $14.9,14.7,14.6$, and 14.5 tons/acre $(33.40,32.95,32.73$, and $\left.32.50 \mathrm{t} \cdot \mathrm{ha}^{-1}\right)$, respectively.

Leaf color ratings varied significantly among the cultivars tested (Table 2). 'Catalina' had significantly higher color than all other entries in the trials. It had a rating of 4.0 and 'Olympia,' 'Padre,' and 'Cypress' had ratings that were 3.4 or higher which was significantly higher than a majority of other cultivars in the trials. Although 
previous trials (Dainello et al.,1984; Gorini and Testoni, 1990) were rated for color, recent work by Murphy and Morelock $(1999,2000)$ indicate that high levels of green color intensity may be linked to higher levels of lutein. This may very well make leaf color ratings an important aspect of spinach cultivar testing in the future, particularly as consumers become more conscious of the nutritional value of their food.

Cultivars with significantly higher levels of resistance to bolting included 'Baker,' 'Bolero,' 'Catalina,' 'Olympia,' and 'Padre' which had $1 \%$ or less bolting at harvest (Table 2). Cultivar bolting resistance is a major consideration for commercial producers of spring spinach. Spinach fields that have only $10 \%$ bolting plants are unacceptable and would not be harvested.

'Catalina,' 'Olympia,' 'Padre,' 'Baker,' and 'Bolero' are the five cultivars tested that can be recommended for use as March-planted spinach for commercial production in Oklahoma and the southern plains. These cultivars had significantly higher levels of resistance to bolting which is the key factor that must be considered when selecting cultivars for spring production. However, there were differences among these cultivars in color. Color ratings indicate that 'Catalina,' 'Olympia,' and 'Padre' had darker green color which may indicate a higher level of lutein content. If color is not a consideration for producers, then 'Baker' and 'Bolero' could also be added to a list of potential cultivars.

\section{Literature cited}

Chun, C., M. Tominaga, and T. Kozai. 2001. Floral development and bolting of spinach as affected by photoperiod and integrated photosynthetic photon flux during transplant production. HortScience 36(5):889-892.

Dainello, F.J., R.K. Jones, and R.R. Heineman. 1984. Evaluation of selected spinach varieties under early, mid and late planting conditions. Texas Agr. Expt. Sta. PR 4198:1-8.

Dainello, F.J., R.R. Heineman, and M.C. Black. 1987. Bolting and yield characteristics of processing spinach varieties in the Texas winter garden. Texas Agr. Expt. Sta. PR 4508:1-9.

Dainello, F.J. 1989. Radicle dehydration of germinated seed on seedling emergence and vigor in spinach. HortScience 24(6):935-937.
De Rooster, L. and K. Spiessens. 1998. Summer cultivation of spinach. Proeftuinnieuws 8(23): 25-26.

Djurovka, M., B. Lazic, and V. Markovic. 1988. General characteristics of spinach varieties suitable for industrial processing. Acta Hort. 220:159-164.

Goldman, I.L. 2003. Recognition of fruit and vegetables as healthful: Vitamins and phytonutrients. HortTechnology 13(2):252-258.

Gorini, F.L. and A. Testoni. 1990. The relation between colour and quality of vegetables. Acta Hort. 259:31-43.

Knott, J.E. 1939. The effect of temperature on the photoperiodic response of spinach. Cornell Univ. Agr. Expt. Sta. Memoir 218:1-38

Leskovar, D.I., L.A. Stein, and F.J. Dainello. 2000. Planting systems influence growth dynamics and quality of fresh market spinach. HortScience 35(7):1238-1240.

McCord, H. and G. McVeigh. 2000. Nutrition news. Prevention 52(6):60-64.

Murphy, J.B. and T.E. Morelock. 1999. Carotenoid antioxidant levels in spinach: preliminary screening. Res. Ser.-Arkansas Agr. Exp. Sta. 466:106-108.

Murphy, J.B. and T.E. Morelock. 2000. Spinach breeding program yields lines containing high levels of carotenoid antioxidants. Res. Series-Arkansas Agr. Exp. Sta. 475:36-39.

Silva, B. 2002. Merchandising spinach. Produce Business 18(11):45-48.

Sneep, J. 1982. The domestication of spinach and the breeding history of its varieties. Euphytica Suppl. p. 1-27.

Tonini, G., P. Pasini, and L. Dal Re. 1987. Quality of deep frozen spinach as related to cultivar field performance. Acta Hort. 220:461-464.

U.S. Department of Agriculture. 1995. Vegetables 1994 summary. 13 July 2004. <http://jan.mannlib.cornell.edu/reports/nassr/fruit/pvg-bban/vgan0195. txt>.

U.S. Department of Agriculture. 2003. Vegetables 2002 summary. 13 July 2004. <http://jan.mannlib.cornell.edu/reports/nassr/fruit/pvg-bban/vgan0103. pdf>.

Williams, T.V and W.B. Roberts. 2002. Is vegetable variety evaluation and reporting becoming a lost art? An industry perspective. Hort Technology 12(4):553-559. 